\title{
ЭСТЕТИКА
}

\author{
А.В. Беликов
}

DOI: 10.7256/1999-2793.2014.11.13368

\section{ЭСТЕТИКА ВОЗВЫШЕННОГО \\ И КАНОН В ПОЗДНЕАНТИЧНОМ \\ И ВИЗАНТИЙСКОМ ИСКУССТВЕ}

\begin{abstract}
Аннотация. Вопрос о культурных и мировоззренческих причинах возникновения христианского искусства в позднеантичное время представляет собой и поныне малоизученную проблему. Истоки возникновения такого уникального явления как изобразительный канон, который определил самобытность византийского искусства также остаются во многом неизвестны, на фоне сравнительной изученности канонического искусства. Статья затрагивает проблемы художественного освоения эстетического и духовного опыта в раннехристианскую и византийскую эпоху. Рассматривается проблема возникновения эстетических концепций и трансформация художественных канонов, смена эстетического модуса, отказ от идеи прекрасного и замена его идеей возвышенного. Особое внимание посвящено изучению путей и способов реализации анагогического опыта в искусстве и рассмотрению места творческой фантазии как особой формы эстетического опыта, суть которого заключается в способности человека усилием воли увидеть в уме образ, не являющийся воспоминанием реального. Специфика проблемы, лежащей на стыке эстетики, теологии, культурологии и искусствознания диктует необходимость применения междисциплинарных методов $\mathrm{c}$ привлечением максимально широкого круга источников. Канон предстает как набор правил и рекомендаций, обеспечивающих художественную фиксацию специфического для восточного христианства духовномистического опыта, называемого анагогическим. Канон выступает как механизм, регламентирующий работу творческого воображения мастера-иконописца. Само воображение определено как специфическая форма мнимого пространства, в котором и получают визуальное оформление, становятся образами умозрительные категории, постижение которых является целью и смыслом анагогического опыта.

Ключевые слова: византийский канон, икона, мистический опыт, фантазия, эстетический опыт, символ, художественный образ, возвышенное, миметическое изображение, анагогия.
\end{abstract}

K ризис поздней империи затронул все стороны жизни граждан Рима. Разочарование в старых богах и пантеонах и поиск новых духовных ориентиров сопровождался ощущением оскудения философских систем, господствовавших с классического времени. Разнообразные восточные мистические учения сделались чрезвычайно популярны по всей империи. Митраисты, герметисты, гностики, орфики, почитатели Изиды, христиане жили и проповедовали своё вероисповедание на фоне заката традиционных римских культов и римских ценностей, многие из этих учений причудливым образом соединялись с философскими школами, порождая такие явления как гностицизм. Чрезвычайная популярность мистических культов на фоне римского рационализма есть убедительное свидетельство актуали- зации духовного созерцания и его секуляризации. Мистический опыт перестал быть уделом исключительно жреческой профессии и приобрел массовый (и в основном простонародный), характер. Массовый характер этого опыта неожиданно стал важным политическим и культурным фактором жизни империи. Просвещенного римлянина эта непосредственность общения с Творцом шокировала. Яростный критик христианства, рационалист Цельс пишет: «Евреи и христиане кажутся мне стаей летучих мышей или муравьев, выползающих из своей дыры, или лягушками, устроившимися возле своего болота, или же червями, скопившимися в болотной грязи и рассуждающими друг с другом: "Именно нам Бог возвещает о ходе всех вещей; ему нет никакого дела до всего остального мира; он забросил небеса и землю, предоставив их самим себе, 
чтобы всещело заняться нами"»'. Эта насмешка над религиозной восторженностью христиан на деле обнажает страшное, космическое одиночество самого блестящего ритора эпохи, профессионального философа-скептика, товарища Лукиана. Истоки этого ощущения следует искать в раннеантичных синкретичных еще представлениях о природе вещей. Дело в том, что древнейшие античные философские школы развиваются в общем ключе представления о единстве принципов управляющим мышлением и объективной реальностью. Понятие «логос» описывает этот принцип. Единство и сопричастность мысли мыслимому составляет основу античной логики со времени Парменида. Логос, господствующий над универсумом также осуществляет свою власть и над человеком. Обстоятельства и перипетии человеческой жизни развиваются с последовательностью и неотвратимостью физических законов. У Гераклита душа человека также включена в круговорот обращающихся стихий. И сама душа у античных мыслителей вполне материальна, атомарна хоть и составлена из тонкой «эфирной» материи. Художественный образ этой неизбежности «ананке» мы находим еще у гомеровских героев, например когда речь идет об Ахилле. Платон в «Государстве» упоминает о том, что между колен Ананке, богини неотвратимости, вращается веретено - мировая ось.

Возмущение Цельса объяснимо, - ведь для античного философа предел возможностей - бесстрастное принятие неизбежности, и даже боги покорны судьбе. Фатум даже наимудрейшего ставит в трагичное положение бычка из детского стихотворения «доска моя кончается, сейчас я упаду». Христианское упразднение этой неизбежности выглядит совершенно непростительным панибратством для римского мыслителя.

Опыт Спасителя совершенно изменяет саму основу организации мышления. Христос-Логос как меч острый прорезывает реальность жизней, доселе организованных и упакованных в аккуратные соты индивидуальных судеб. Непосредственное богообщение в эпизоде с молением о Чаше и последовавший добровольный крест совершенно отличают Христа и от Сократа и от Орфея, пребывавших в оковах предопределенности. Христос свободен, и смерть - торжествующий голос этой свободы. Собственно такой

\footnotetext{
1 Origene. Contra Celsum IV, 23. (Цит. по: Аман А.-Г. Повседневная жизнь первых христиан 95-197. М.: Молодая Гвардия-Палимпсест, 2003. С. 141).
}

принципиальной декларацией свободы являются массовые добровольные мученичества ранних христиан в эпоху до миланского эдикта 313 г.

В описанном духовном контексте логический материализм Парменида утрачивает свою власть над мышлением, ведь принципиальная констатация свободы человеческой души обуславливает её разрыв с законами материального мира. Человек, разумеется, не полностью свободен, пребывая в теле, как в темнице, о чем напоминает Климент Александрийский, законы материальности более не властны над ним, сама идея долженствования природного закона над душой утрачивает свою власть. Мысль как действие души более не единосущна предмету, она дематериализуется, не нуждаясь более ни в атомах, ни в стихиях. Мысль отныне причастна горнему миру, она теперь единосущна эйдосам.

Такими были обстоятельства, в которых рождалось новое искусство. Новый духовный опыт требовал освоения, оформления. Результатом стало возникновение новых эстетических концепций и нового искусства, при этом развитие философии и изобразительности часто шло параллельно, независимо друг от друга. Художественная практика, будучи отражением непосредственно мистического опыта, часто опережала в своем развитии теологические и философские концепции. Следует особо отметить принцип нераздельности эстетического и мистического опыта, который, возникнув в позднеантичное время, стал основой византийской эстетики.

Рождение новой философской теории образа, а с ней и нового канона связывается с актуализацией переживания вознесенности, напряженным религиозным поиском первых веков новой эры, который повлек за собой смену всех культурных доминант и эстетических приоритетов. Вместе с ним актуализировалось и понятие возвышенного как особого способа передачи Божественного. Понятие возвышенного известно с античного времени, однако в первые века н.э. оно совершенно не связывалось с областью пластических ремёсел-технэ. Возвышенное относилось к области мусических искусств: трагедии, поэзии, музыке и связывалось с аристотелевой интерпретацией катарсиса как очищения через сопереживание, которое, в свою очередь, восходит к элевсинским мистериям.

Христиане противопоставили собственный духовный опыт всему конгломерату позднеантичной культуры. Это противопоставление первоначально сводилось к эстетике отрицания. В III веке появился трактат «0 возвышенном», приписываемый Лон- 


\section{Философия и культура 11(83) • 2014}

гину, ритору I века. В этом трактате впервые явно прослеживается противопоставление возвышенного и прекрасного. Ритор сопоставляет ораторские мелисмы, придающие речи изящество, и возвышенное в словах оратора, которое видится как «отблеск величия души», и может проявляться и в молчании. Современник псевдо-Лонгина, Августин связывает древнее понятие катарсис с темой нравственного перерождения личности ${ }^{2}$. Нравственное представляется «истинной красотой» и, по выражению Климента Александрийског ${ }^{3}$, возвращением утраченного в грехопадении подобия, о котором писал ещё Филон. Такая возвышенная нравственная красота часто напрямую противопоставляется телесной. Так, Тертуллиан, рассматривая кенозис, говорит о невзрачном телесном облике Спасителя ${ }^{4}$ буквально понимая forma servi из Послания филиппийцам. Скрытое Божественное достоинство Христа противопоставляется явному телесному великолепию языческих идолов. В соответствии с этой концепцией именно человек, нравственно очистившийся через подражание Христу, становится подлинной Его иконой. Так рассуждали большинство апологетов.

Среди христиан из язычников очень рано, уже с I в. появляются сторонники платонизма. Связь позднего платонизма с мистическими учениями Востока обеспечила приток платоников в число христиан. Особенно привлекательным для платоников было монотеистическое учение. Деятельность Филона представляет одну из первых попыток совмещения философского аппарата платонизма с монотеистическим религиозным учением. То, что осталось теорией у Плотина, с успехом стало реальностью для последователей апостола Павла. Он и Иоанн Богослов первыми применяют терминологию платоников в своих вероучительных текстах. Раннехристианские апологеты из платоников разочарование в мимесисе совместили с платоническим учением об изображении как о подобии подобия и, в итоге вовсе отказались от использования образов в религиозной практике.

Александрийски мыслившие апологеты толковали изобразительность в платоновом ключе.

\footnotetext{
2 Ratzinger J. Volk und Haus Gottes in Augustins Lehre von der Kirche. München, 1954. S. 41.

3 Бычков В. В. Эстетические взгляды Климента Александрийского // ВДИ. 1977. № 3. С. 81.

4 Тертуллиан (De Carne Christi. 9). (Цит. по: Тертуллиан. Апология. М.: АCT. 2004. (http://www.biblestudy.ru/lib/ patrologia/27383-apologiya-tertullian))
}

Живописные изображения Климент вслед за Платоном делит на два типа: истинные и ложные. Миметические изображения предстают обманкамиидолами: «Искусство обманывает и обольщает [...], увлекая если не к любви, то во всяком случае к уважению и почитанию статуй и картин» (Климент. Протрептик. IV) ${ }^{5}$. Такой религиозный пуризм, идущий от христиан апостольского века, часто сводился к полному отрицанию изобразительного искусства, замене его системой более или менее условных знаков и эмблем типа виноградной лозы, креста, якоря, рыбы. В ходу у ранних христиан также были некоторые буквы греческого алфавита, nomena sacra, различные монограммы. Христиане также активно использовали аллегорические изображения вроде Орфея или Доброго Пастыря для обозначения Христа. Аллегории и эмблемы были в ходу вплоть до Трулльского собора 691 года, 82 правило которого обязало изографов писать Спасителя в образе человека. В то же время иконоборцы VIII в. только такие изображения дозволяли для размещения в церквах.

Развитие идеи знака идёт от восточных традиций, аллегория - хорошо известный античности приём, - эти принципы использовали в своём искусстве художники катакомб. Сравнение образов из христианских катакомб с помпейской живописью IV стиля, о которой шла речь выше, позволяет отметить одну чрезвычайно важную тенденцию. Отказавшееся от мимесиса в пользу творческой фантазии, языческое искусство пленительно прекрасно, в то время как фрески катакомб будто намеренно отказываются быть красивыми, языческие фрески туманны и неясны, христианские предельно настроены на максимальную ясность, искусство Помпей пространственно иллюзорно, многие фигуры катакомб помещены на выбеленном, будто раскалённо-выжженом фоне. Эти различия обозначают наметившуюся смену модуса, резко обособившую христианское искусство от современного ему искусства язычников задолго до возникновения любых художественных правил этого нового искусства.

Смена эстетического модуса, отказ от идеи прекрасного и замена его идеей возвышенного имеет следствием фундаментальное изменение ис-

Пропретрик, гл. 4. Цит. по: Климент Александрийский. Увещевание к язычникам / Пер. А.Ю. Братухина. СПб.: Издво РХГИ, 1998. 208 с. 
кусства на самом его глубинном уровне. Дворжак ${ }^{6}$, сравнивая христианское катакомбное искусство с современными ему языческими памятниками, обнаруживает это фундаментальное отличие и относит его к области «художественных намерений». Если ранее художник, берясь за кисть, стремился сделать изображение красивым, таким, чтобы действие этой красоты увлекало зрителя и удерживало его внимание на предмете, теперь целью мастера было сделать зрителя свидетелем созерцания Того, кто превышает любую земную красоту, будучи самим подателем красоты и блага. Всё это не может быть выражено ни с помощью античного механизма аллегории, ни с помощью египетского механизма священного знака-иероглифа, ни чемлибо в структуре греко-римского канона.

Будучи первым обращением христианского искусства к теме возвышенного, фрески катакомб II-III вв. отличаются и от современного им языческого искусства, и от классической иконы. Это отличие лежит в функциональной области. Отличие от античного искусства состоит в том, что эти фрески уже в топологии своей представляют собой свидетельство горнего. Конечно фрески катакомб возникли не в пустоте. В значительной степени они наследуют эстетическую парадигму современных им восточных образов, в частности пальмирских погребальных изображений, о которых С. Аверинцев сказал: «ближневосточные ваятели первых веков нашей эры, нашупавшие в пределах античного искусства скульптуры новые, неантичные возможности экспрессии, начали просверливать буравом зрачки свочх изваяний, глубокие и открытые, как рана....изваяние, по своей внутренней форме - уже икона: тело - только подставка для лица, лицо только обрамление для взгляда, для экспрессии пробуравленных и буравящих зрачков» ${ }^{7}$.

И все же, образы катакомб, хотя и включали в себя набор черт характерных для канонической иконы, главную функцию иконы не выполняли. Они не подразумевают молитвенного общения, то есть не являются иконами в современном понимании, поскольку смысл изображения в христианской эстетике мыслится в первую очередь через призму реального непосредственного богообще-

6 Dvořák M. Kunstgeschichte als Geistesgeschichte («Katakombenmalereien. Die Anfänge der christlichen Kunst»). München, 1924. S. 3-40.

7 Аверинцев С.С. Поэтика ранневизантийской литературы. СПб: Азбука-классика, 2004. С. 66. ния. Хотя некоторые образы катакомб имеют свою, совершенно особую выразительность, сама логика репрезентации катакомбных изображений всё еще подчинена канонам античного искусства. Фрески катакомб - это изображения, не имеющие еще анагогической функции, хотя и являющиеся убедительными свидетельствами мистического опыта первых христиан и наиболее ранними примерами искусства, развивающегося в модусе возвышенного. Ничего подобного античное искусство не предполагало. Эстетический поиск платоников, главных античных теоретиков идеального образа, всегда упирался в непреодолимость границы между миром идей и миром вещей. Христианство сумело преодолеть границу дольнего и горнего через идею встречного движения человека и Бога, выраженного в идеях теозиса и кенозиса. Способность вневременного и внепространственного Божества к умалению и помещению себя в систему пространства-времени дольнего, делает самого человека совершенным образом Бога и формирует теоретическую базу для возникновения иконы. Икона становится не просто изображением, возводящим ум к духовным сущностям, но и носителем возвышенного, окном и оком горнего в дольнем.

Кризис аристотелева мимесиса, доминировавшего в изобразительном искусстве со времени эллинизма, был вызван неприспособленностью принципа отображения для передачи духовного опыта. При всем потрясающем богатстве изобразительных возможностей античного искусства, его выразительные возможности ограничивались художественной передачей душевных, психических состояний. Духовный опыт, однако, обозначает нечто большее, и от изобразительности требуется нечто большее, чем отражение психического состояния, ведь в опыте духовного созерцания человек, соединяясь с Всевышним, превышает себя. Духовный опыт в позднеантичное время не был явлением исключительным, и сконцентрированным лишь в границах христианской общины. Поэтому сопутствующее этому опыту разочарование в миметическом искусстве и поиск новых выразительных средств также были предметом интереса самых различных групп, школ и течений. Важно отметить, что поиск выразительных средств в искусстве, в отличии от поиска изобразительных средств является уделом не столько художникапрактика, сколько задачей теоретика. Грекоязычная интеллектуальная элита позднего Рима занималась интенсивным поиском новых источников 


\section{Философия и культура 11(83) • 2014}

художественного творчества, лежащих за пределами чувственного восприятия, эстемы, о недостоверности которой шел разговор еще со времени досократиков. В эпоху Северов впервые возникает понятие для обозначения эстетического опыта, суть которого заключается в способности человека усилием воли увидеть в уме образ, не являющийся воспоминанием реального. Такого рода опыт не имеет аналогов ни в иудейской традиции, для которой характерно более или менее спонтанное пророческое визионерство, ни в античной традиции, которая связывает идеальное иконическое искусство с гармонией математически рассчитанных числовых пропорций. Флавий Филострат, теоретик искусства из круга императрицы Юлии Домны, жены Септимия Севера, жившей на пороге II-III вв., размышляя в рамках идеи трансформации второго типа аристотелевой типологии мимесиса, и следуя при этом Сексту Эмпирику, из лексикона

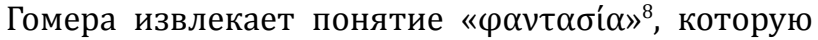
он восхваляет, называя «более мудрым творцом, чем подражание» ${ }^{9}$ и предлагает ее в качестве основы для трансформации всей сферы пластического. Размышляя в рамках идеи трансформации второго типа аристотелевой типологии мимесиса Флавий Филострат со ссылкой на Гомера описывает такое

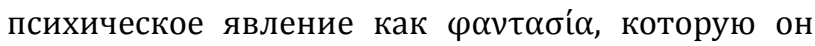
восхваляет: «...работа воображения, <...> она куда искуснее подражания, ибо подражание создает лищь виденное, а воображение - еще и невиданное, творя возможные, хотя и небывалые образы. Подражанию частою помехою бывает изумление, а воображению нет помехи, ибо не смутят его собственные мечтания» ${ }^{10}$. (VI, 19).

Хотя античность со времени создания Аристотелем трактата «0 душе» знала об этой способности сознания создавать образы, не имеющие аналогов в реальности, именно Филостраты сделали его эстетической концепцией. Возможности творческого применения фантасии для художника классической античности ограничивалось созданием комбинированных изображений вроде химеры, кентавра, или сфинкса. В эпоху Фило-

\footnotetext{
8 См. также: Schweizer B. Mimesis und Phantasia // Philologus. 1934. Bd. 39. S. 286-300.

9 Флавий Филострат. Жизнь Аполлония Тианского. М.: Наука, 1985. (http://krotov.info/acts/03/1/filostrat_00.htm).

10 Флавий Филострат. Жизнь Аполлония Тианского. / Изд. подг. Е.Г. Рабинович; Отв. М.Л. Гаспаров. М.: Наука, 1985. C. 131-132.
}

стратов актуализация идеи фантасии вызвала к жизни иной тип эстетического мышления. До нашего времени дошло искусство такого типа - оно относится к кругу помпейской живописи IV стиля, с её эфемерными пейзажами, фантастической архитектурой, странными, подчас гротескными персонажами, как будто увиденными во сне. Живопись этого времени часто называют позднеантичным «импрессионизмом». И всё же, это искусство основано на принципах классической эстетики с идеей подражания прекрасному. Дополненное эллинистической идеей подражания природе, это миметическое искусство даже дальше от платоновой трактовки иконического, чем живопись Зевксиса. Для Флавия Филострата природа (фюзис) первична. Образы-впечатления реальных вещей комбинируются в сознании художника, приобретают новые подробности, приукрашиваются и затем становятся художеством. Несмотря на увеличение роли сознания в творческом процессе, в основном искусство II-III вв. остаётся тектоничным, телесно ориентированным, пространственным, многоплановым по своей структуре. Рождённая в языческой, даже антихристианской среде идея $\varphi \alpha \nu \tau \alpha \sigma i ́ \alpha$ соединилась с идеей творческой воли. Очень скоро фантасия становится частью эстетической парадигмы иконы. Экфрасис Хорикия из Газы, христианского писателя VI в., описывающий росписи церкви Св. Георгия в Газе, приводит сцену Благовещения: «Крылатое существо только что сошло с небес по фантазии художника и пришло к той, которая будет матерью без мужа» ${ }^{11}$. Газский ритор прямо указывает на фантасию как на источник творческого замысла. Позднее в христианском каноне идея фантасии занимает место, предусмотренное в античном каноне представлением об акривии, когда канон дозволяет художнику, и даже провоцирует его на небольшие отклонения от схемы, своеобразную авторскую трактовку образа.

Однако сама по себе творческая фантазия не могла стать фундаментом нового искусства. Фантазия индивидуальна по природе, в то время как мистический опыт имеет общинный характер. Задача передачи этого опыта требует формирования общепринятого художественного языка. Новая эстетика потребовала замены всей структурно-конструктивной модели искусства, что выразилось, в первую очередь, в преодолении границ аллегории и форми-

11 Цит. по: Mango C. The art of the Byzantine Empire 3121453. New Jersey, 1972. P. 60-68. 
ровании понятия «символ», которое стало высшей реализацией в искусстве принципа возвышенного. Именно это понятие определило облик христианского искусства Средних веков. Средневековый канон предстает в первую очередь как инструмент художественной реализации идеи символа. Символ же, в свою очередь, представляет собой уже не простую античную метаболу, но гораздо более сложное явление, осуществляющее помимо упомянутых дидактико-информативной, коммеморативной и декоративной функций, две дополнительные и наиболее важные: анагогическую и харисматическую $^{12}$. С одной стороны, будучи носителем возвышенного, образ согласно Иоанну Дамаскину, возводит ум «чрез телесное созерцание $к$ созерцанию духовному» ${ }^{13}$, образ (словесный или живописный) способен, по словам Дионисия Ареопагита, возводить, восхищать сознание: «мы чувственными образами возводимся, насколько возможно, к божественным созерцаниям» ${ }^{14}$. С другой стороны, образ, также как и литургические предметы, согласно Иоанну Дамаскину, несет в себе божественную благодать (харисму), соприсутствующую ему «ради имени изображенных», и не связанную с художественными материалами и, что важнее, с художественным качеством изображения. Наиболее сложной в художественной реализации представляется анагогическая функция образа, поскольку для того, чтобы создать образ, способный возводить ум созерцающего к первообразу, необходимо, чтобы сам мастер, помимо высокого уровня художественного ремесла, в момент создания образа пребывал «в духе», только тогда образ является отражением мистического опыта художника и способен реализовывать свою анагогическую функцию. Указанный аспект составляет особенность действия канона в границах анагогической парадигмы изобразительного искусства, поскольку в этом случае нормативная роль канона не может однозначно предопределить успех или неудачу художественного произведения. Для языческого мастера решение такого рода ситуации регулировалось акривией, которую можно трак-

12 Бычков В.В. Феномен иконы: История. Богословие. Эстетика. Искусство. М.: Ладомир, 2009. С. 70-71.

13 Цит. по: Бычков В.В. Малая история византийской эстетики. Киев, 1991. С. 170.

14 Дионисий Ареопагит. Корпус Ареопагитикум. О церковной иерархии. (Цит. по: Восточные отцы и учители Церкви V века. Антология. М.: Изд-во МФТИ, 2000. (http://krotov. info/acts/05/antolog/page26.htm)). товать как точность в следовании установленных каноническим схемам. Средневековый канон, будучи частью церковного ритуала, способен сподвигнуть художника на труд, он облегчает достижение состояния вознесенности, в самой последовательности художественных действий он несет отпечаток пути к достижению состояния возвышенности, проделанного десятками мистиков-иконописцев прошлого, однако выполнение всех этих правил не даёт гарантии результата. Очевидно, что состояние вознесенности есть исключительное для человека переживание. И не всякий художник способен этого состояния достичь. В то же время нужды религиозного культа требуют массового производства сакральных изображений. В такой ситуации мастер нуждается не только в партитуре, но и в инструкции, содержащей подробное описание процесса создания художественной вещи. В результате для гения-мистика канон предстает партитурой, а для палехского артельщика - инструкцией, сборником рецептов, папкой образцов. Выделяющееся в общем ряду художественное произведение само приобретало статус образца и порождало определенный иконографический тип. Так, например, стоглавый собор предписывал всем художникам писать образ Троицы так, как писал его Андрей Рублев ${ }^{15}$.

Такая ситуация порождает неравенство в возможностях реализации анагогической и харисматической функций в каноническом христианском искусстве.

Как убедительно показывает опыт катакомбного искусства, одного только переживания вознесенности, соединенного с христианским чувством и высоким античным художественным навыком, недостаточно для создания анагогических изображений. Мистический опыт апостола Павла по дороге в Дамаск демонстрирует, что вознесенное состояние далеко не есть еще увиденный образ, и уж тем более не образ-свидетельство ${ }^{16}$. Требуется особая форма визионерского эстетического опыта, схожая скорее с опытом Иоанна Богослова или даже опытом апостола Фомы, обычно обозначаемая в христианстве как Откровение. Переживание вознесенности, как его описывают древние есть во многом спонтанное состояние, схожее по своим признакам с синдромом Стендаля, в то время, как Откровение есть резуль-

15 Стоглав / Изд. Д.Е. Кожанчикова. СПб., 1863. С. 128.

16 Салтыков А.А. Достоверность свидетельства: понятие «прографо» в послании к Галатам. Искусство Христианского Мира. Вып. 8. М.: Изд-во ПСТБИ, 2004. С. 5-16. 


\section{Философия и культура 11(83) • 2014}

тат взаимонаправленного движения человеческой воли, страстно желающей увидеть, и Всевышнего, раскрывающего себя молящемуся.

Средневековое восприятие фантасии, трактуемой как воображение (т.е. способность внутренним взглядом увидеть надмирные сущности как конкретную и потенциально изобразимую форму), формируется уже язычника-неоплатоника Плотина. Именно его трактовка становится частью эстетической парадигмы христианского изобразительного канона. Именно Плотин видит в воображении форму познавательной способности. Так же как Платон и Аристотель, Плотин трактует воображение как способность души образовывать и удерживать в памяти психические образы. Его теория образа закладывает основные принципы художественной реализации идеи символа. Именно он, задолго до Дамаскинова рассуждения о харисме, заводит разговор об отблеске горнего, соприсутствующего материальным вещам. Плотин называет это внутренним эйдосом: «Если же кто-то бесчестит искусства, ибо они творят, подражая природе, то ему должно прежде всего сказать, что и [отдельные] природные вещи тоже подражают [в своем творчестве природе]. Кроме того, он должен знать, что искусства не просто подражают видимому, но возводят свой взгляд к логосам, из которых происходит природа. Помимо этого, они многое делают от себя, и, как обладающие красотой, они добавляют к вещам то, чего им не хватает. Ибо и Фидий сотворил Зевса, взирая отнюдь не на чувственное, но постигая [умом], как выглядел бы Зевс, если бы пожелал явиться нашим очам» ${ }^{17}$ (Эннеады V 8, 1, 38). В трактате «О прекрасном» Плотин описывает основные характеристики внутреннего эйдоса, который совмещает в себе некоторые черты аристотелевой энтелехии и платонового эйдоса, отличаясь от них обоих. Устанавливая связь между прекрасным и восприятием, он утверждает, что когда речь идет о телах, предметах, красота находится внутри них самих, Плотин указывает на то, что красота эта не есть следствие симметрии, соразмерности частей, как полагал Платон. Ощущение прекрасного не есть также результат гармонии стихий, или гармонии размеров. Плотин разрушает казавшуюся незыблемой связь между идеей гармонии отношений, красотой, и добродетелью, которая также мыслилась как атараксия -

17 Плотин. Эннеады. Т. V. СПб.: Изд. Олега Абышко, 2005. C. 212 . форма гармонии души, не колеблемой аффектами. Так опровергается античная идея калокагатии. Он указывает на абсурдность применения к душе понятия симметрии. Внутренний эйдос Плотина не содержится ни в материи, ни в отношениях частей, напротив сама материя должна участвовать в эйдосе чтобы стать прекрасной, это участие делает прекрасное тело целым, то есть придаёт ему форму. Материя не причастная эйдосу не имеет образа, она без-образна, бесформенна. Внутренние эйдосы занимают промежуточное положение между эстемой (результатами недостоверного чувственного восприятия) и умопостигаемыми сущностями. Это промежуточное положение делает их фактами воображения и придает образу характер инструмента, с помощью которого недискурсивное знание, полученное в умном опыте, приобретает характер зримого, увиденного, хотя и не плотскими очами. Таким образом, знание, полученное в анагогическом опыте, приобретает характер увиденного и, следовательно, воплотимого. Конечно, художественное воображение требует от мастера интенсивного воления (kunstwollen), устремления к высшему, в противном случае сказывается его двойственная, промежуточная природа. Ибо, имея родство с телесным, воображение причастно небытию и способно порождать образы, не имеющие первообраза, идолы, или фантасмы, отсылающие не к Первообразу, но к Иному. Также воображение способно произвольно сопрягать виденное, создавая образы не невидимого, но невиденного, такие, как пресловутые сфинксы, кентавры, химеры, то есть воображение склонно становиться простым вымыслом. Однако родство воображения с горним открывает путь к созданию образов воображения, - иконических, которые, в отличие от миметических, точны и способны являть не только телесные предметы, но и невидимые, вечные и неизменные идеальные объекты и их свойства ${ }^{18}$. Плотин различает две способности воображения - высшую, синтезирующую и воспроизводящую данные чувственного восприятия, относимую к высшей, не связанной с телом, душе, а также низшую способность воображения, неопределенную и нерасчлененную, относимую к воплощенной в теле душе (Энн. IV. 3.31: ср. III. 6.4.).

18 Ср. Энн. 1.8.14-15; III. 6.15; IV. 6.3: Прокл. Комм. к Евклиду 51-56,78-79, КОММ. к “Тим.” Ill 235, III 286-287; Порфирий. Сент. 8,16, 37,43, 47-48, 54-55; Сириан. Комм. к “Мет." 98 ел. 
Говоря о Воображении Плотин, развивая идеи Аристотеля (Метафизика VII 10-11 b VIII 6: ср. Энн. II. 4.1-5), говорит о воображении как об особой форме протяженности, не имеющей, впрочем, физической природы. Этот логический ход позволяет преодолеть ставшую проклятьем платонизма пропасть между миром идей и миром вещей. Поскольку воображение представляет свои образы как протяженные, оно и само может быть уподоблено некоему протяжению, впрочем, не физическому, в котором могут воплощаться в тела геометрические фигуры, имеющие у Платона статус промежуточных между физическими вещами и их эйдосами. Как показывает Прокл, геометрические объекты воссоздаются и представляются из своих идеальных прообразов в воображении (подобно тому, как слова являются продуктом рассудка и воображе-

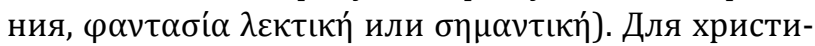
анства следующего логике творения Словом, воображение предстает тенью утраченного Подобия, оно становится одним из центральных элементов анагогии. О состоянии вознесенности, сопровождаемом работой воображения, пишет Иоанн, экзарх болгарский: «Како ти се въземлет ум выше небес и акы боголепная та места виде се сътвориши, и сладькая, и славная, и светлая, и с теми святыми радуесе, хваливши бога, в красных тех месьтех. И позор (зрелище - Д.Л.) дивън видиши, и весельство. Да како убо ум сьи душа в бренънем сем телесе се привезанъи храм над собою имее покров и над тем пакы въздух, и етерь (эфир - Д.Л.), и небеса вса. И тамо мыслию възидеши к богу невидимуему. Како ли ти сквозе храм пролета ум и всю ту высость, $и$ небеса, скорее мъжения очнааго прилетев...» ${ }^{19}$.

Чем является тело увиденное-в-уме и не имеющее материального прототипа? Художественный образ, существующий лишь как проекция сознания художника. Понятно, что греческий мастер вполне мог выстроить образ, тело его, пользуясь каноном Поликлета и принципами ритма, симметрии и акривии. То был бы образ лишенный двух принципиальных для верующего вещей - индивидуальности (или ипостасности) и выразительности. Такой образ не был бы приспособлен для анагогии. Это была бы просто идеальная форма. Воображение

19 Шестоднев, составленный Иоанном, ексархом болгарским, по харатейному списку Московской синодальной библиотеки 1263 года. (Цит. по: Лихачев Д.С. Поэтика древнерусской литературы. Избранные труды в 3-х тт. Т. 1. Л., 1987. C. 639). стало тем обстоятельством, которое преобразило принципы художественного творчества. При этом воображение должно иметь ограничивающий его движение определенными пределами механизм, встроенный в психику мастера, в противном случае неудержимая фантазия не подчиненная религиозной воле и не сдерживаемая каноном будет порождать тёмные, смутные образы Иного.

Одним из первых о Плотине как о предтече средневековой изобразительности заговорил А. Грабар ${ }^{20}$. Он определил набор параметров, характерных для образа увиденного в уме, исходя из топологии воображения увиденного Плотином как специфического пространства. Собственно эти требования и составляют специфический облик канонического искусства христианского Востока. Эти принципы не канонизированы, но, тем не менее составляют основу канонического художественного мышления. Это три требования истинности: размера, дистанции, цвета. Все эти принципы описывают механику работы воображения, которая характеризуется в первую очередь упразднением субъектно-объектных переживаний. То есть, воображение помещает не только образ внутрь сознания, но и сознание внутрь образа. В первую очередь это касается топологических основ изобразительности. Вся топология изображения строится вокруг идеи отказа от понятия «точки зрения», характерной для чувственного зрения телесными очами. Следствием такого отказа становится исчезновение дистанции между зрителем и зримым. Художественная реализация этого принципа выражена в идее полезного созерцания, т.е. предмет изображается так, чтобы созерцающий мог уяснить все необходимые обстоятельства образа. Плотин пишет: «Там все вещи прозрачны и нет ничего темного или сопротивляющегося взгляду; все явны для всех и в своем сокровенном, и во всем остальном, так как свет прозрачен для света. Каждое Там имеет всё в себе и видит всё в другом, так что всё есть везде, и каждая, и все вещи есть всё, и неделима Слава; каждый из тех [тамошних обитателей] велик, даже и малый велик; Солнце есть Там все звезды, и каждая из звезд есть Солнце и все остальные. Иное - вне каждого из них, но в каждом явлены все. Движение тоже чисто, поскольку движущееся не вносит в него смятения, становясь

20 Grabar A. Plotin et les origines de l'esthétique médiévale // Cahiers archéologiques. Fin de l'antiquité et Moyen Age. 1945. Vol. 1. P. 15-34. 


\section{Философия и культура 11(83) • 2014}

чем-то от него отличным [как это имеет место в процессе всякого из здешних движений]. Покой [Там] невозмутим, ибо не смешан ни с чем беспокойным. И Красота [Там] есть [истинная] Красота, потому что есть не в том, что красиво. Там каждый ступает не по чужому себе и внешнему, например, по земле, но то, на что он ступает, есть то, что есть он сам, и если кто-либо, так сказать, направляется к горнему, тогда то, откуда он туда направляется, движется вместе с ним; он сам не есть - одно, а пространство - другое» ${ }^{21}$. Таким образом, истинное изображение подразумевает отказ от использования перспективы в её современном (прямая одноили многоточечная перспектива) или в античном («рыбья кость») виде. Изображаемое смещается на передний план в границы бинокулярности человеческого зрения, где предметы воспринимаются в изометрической проекции ${ }^{22}$. Собственно только передним планом такая изобразительность и стремится ограничиться, поскольку умозрение полностью сосредоточено на одном предмете и не предусматривает фонового, периферийного восприятия. Враждебность такого искусства по отношению к перспективе выражается не только в полном отказе от передачи глубины пространства в изображении, но и в стремлении преодолеть перспективу там, где она, кажется торжествует, - в архитектуре, создавая монументальную живопись, каноническое искусство подразумевает целую систему антиперспективных приёмов ${ }^{23}$.

Отказ от перспективы приводит, как следствие, к исчезновению идеи развития планов и утрате представления о пространственной роли относительных размеров. Все объекты в изображении оказываются сдвинуты на передний план, а их размер указывает не на степень удаленности от зрителя, а на их статус в священной иерархии. Смысл размерности здесь тот же, что и в увеличении размера фигуры фараона по сравнению с подданными в древнеегипетском искусстве. Истинный размер изображаемого определяется его важностью для зрителя.

Истинность передачи цвета подразумевает стремление передать предмет таким, каков он есть.

21 Плотин. Эннеады. Т. V. СПб.: Изд. Олега Абышко, 2005. C. 217.

22 Подробнее см.: Раушенбах Б.В. Геометрия картины и зрительное восприятие. СПб.: Азбука-классика, 2001. 320 с.

23 Демус О. Мозаики византийских храмов. Принципы монументального искусства Византии. М.: Индрик, 2001. 160 с.
Это обозначает отказ от понятия среды, атмосферы, световоздушной перспективы и светотени. Изограф стремится сообщить изображаемому цвет предмета незамутненного воздушной перспективой, разнообразными тенями и рефлексами. Важен также аспект материальности изображаемого. Результатом становится локальное использование цвета, использование золота в качестве фона, усиление линейного начала в живописи. Свет больше не участвует в лепке формы. Возникает бестеневая живопись, где форма в карнации создается за счет вибраций цвета, а не тона. Такие подчеркнуто дематериализованные образы, тонущие в золотом сиянии, чья вещественность явлена лишь в цвете, делают цвет совершенно особой и чрезвычайно важной характеристикой изобразительности. Цвет осмысляется символически, как нечто, что человек сам не в состоянии создать, в отличие от самого образа, цвет связывает образ с первоначалами. Золото в иконе становится, по выражению С.С. Аверинцева ${ }^{24}$, абсолютной метафорой света невечернего, вечного, нетленного, неиссякающего. Вообще же свет в такой изобразительности утрачивает связь с реальностью и становится внемиметической характеристикой изображения.

Следствием реализации упомянутых принципов является присущее состоянию возвышенности упразднение пространственно-временного контекста. Глядя на образ невозможно сказать, где и когда имело место изображаемое событие, в какое время года, вечером или днем - всё это утрачивает значение как несущественное. Фигуры предстоят верующему, обращаются к нему даже в том случае, если пребывают в диалоге между собой.

Еще одним чрезвычайно важным моментом определившим самостоятельность византийского канонического искусства является его сосредоточенность на лике. Главное отличие византийского канона пропорций от древних канонов состояло в изменении единицы размерности фигуры. Византийский канон взял за основу не длину пальца или ладони, как классический, а высоту лица или головы. Иконный лик есть средоточие и смысл иконы, выражение этого лика, его способность вступать в реальное общение с верующим, принимать молитву, делая обращающегося сопричастным божественной благодати, и есть квинтэссенция анагогической сущности иконы. Экфрасис Церкви

24 Аверинцев С.С. Поэтика ранневизантийской литературы. Золото в системе символов ранневизантийской культуры. СПб: Азбука-классика, 2004. С. 404-422. 
Святых Апостолов Николая Месарита описывает эту особенность иконного лика на примере изображения Пантократора: Он взирает «благосклонно и дружелюбно на имеющих чистую совесть и вливает сладость смирения в души чистых сердец и нищих духом», а для грешника глаза Вседержителя «сверкают гневно», отчужденно и неприязненно, он видит лик его «разгневанным, страшным и полным угрозы» ${ }^{25}$. Астерий Амасийский упоминает о языческом изображении чрезвычайной художественной силы со схожим эстетическим эффектом и дает описание художественного приема, с помощью которого мастер добивается такого эффекта: «видел картину, изображающую известную баснословную женщину Колхидскую (Медею), которая, желая поразить мечем детей своих, выражала в лице своем вместе и сожаление и сильное негодование. Один глаз показывал в ней сильный гнев, другой напротив - мать, которая нежно любит детей своих, и ужасается злодеяния» ${ }^{26}$. Дошел так называемый синайский образ Спасителя где можно увидеть реализацию подобного приёма. В этом живоподобии заключен парадокс канонического искусства средневековья. В отрицании античности, отказе от мимесиса, в стремлении к типичности христианский канон способен все же вызывать к жизни очень личные, интимные, уникальные образы, впитывая в себя лучшее от античного изобразительного искусства. Будучи «выражением невыразимого» и «изображением неизобразимого» икона содержит в себе древнегреческое переживание образа как отражения, в соединении с древневосточной магией имени, которое содержит мистическую суть называемого ${ }^{27}$, укоренившейся среди александрийцев со времени Филона ${ }^{28}$. У истоков этой идеи стоит Василий Великий одновременно признававший миметические образы, и воспроизводивший,

\footnotetext{
25 Heisenberg A. Grabeskirche und Apostelkirche. II. TeiJ. Die Apostelkirche in Konstantinopel. Leipzig 1908, S. 8. издание текста Месарита: S. 9-96 (14)

26 Астерия, епископа Амазийскаго, Слово о иконе св. мученицы Евфимии // Журнал «Христианское чтение, издаваемое при Санктпетербургской Духовной Академии». СПб.: В Типографии Ильи Глазунова и К, 1827. Часть XXVII. С. 33-42.

27 Бычков В.В. Эстетическая аура бытия: Современная эстетика как наука и философия искусства. М.: Изд-во МБА, 2010. С. 58-59.

28 Гагинский А.М. Имя Бога и бытие: Филон Александрийский и Иустин философ Евразия: Духовные традиции народов. М., 2012. № 2. С. 26-33.
}

вслед за Климентом и другими александрийцами, христианизированный вариант иерархии подобий, которую мы встречаем и у Плотина. Наиболее ёмко его позиция выражается формулой Василия Великого: «честь, воздаваемая образу, переходит $к$ первообразу» ${ }^{29}$. В этом принципе можно увидеть отражение логического материализма древних.

Обобщая вышесказанное можно отметить, что в раннехристианское время на фоне кризиса миметического искусства и споров об изобразительности и образе, канон претерпевает существенную трансформацию. Он перестаёт быть только лишь пропорциональной системой, «каркасом» художественной вещи, но становится организующим принципом художественного произведения. Причина этого состоит в наметившимся стремлении к художественной передаче в образе эйдосов духовного мира, живописной реализации умозрительного опыта. Канон, тем самым, представляет собой фиксацию опыта возвышенного, и соответствует переходу изобразительности из модуса прекрасного в модус возвышенного в эпоху становления христианского искусства. Характерная для раннего христианства уподобленность этики и эстетики, будучи модификацией античной идеи калокагатии, обеспечила устойчивую связь изобразительного искусства с религиозным опытом. Будучи связанным с религиозным культом, каноническое искусство очевидно преследует ту же цель, что и сама религия - постижение сокровенного знания во всей его полноте. Каноническое искусство раскрывает перед верующим раз и навсегда явленную истину. Это объясняет сравнительную малоподвижность и высокую степень преемственности христианского искусства. Такое искусство, функционально предназначенное для того, чтобы будучи частью религиозного ритуала, восхищать, «возводить» разум и чувства к постижению истины, принято называть анагогическим. Специфическое состояние, являющееся целью - переживание состояния вознесенности, делает это искусство возвышенным, т.е. противопоставленным искусству, стремящемуся усладить чувство, искусству подражающему земной красоте, т.е. искусству, развивающемуся в модусе «прекрасного».

Будучи формой художественного языка, канон интерпретируется всеми сторонами художественного процесса, - заказчиком-ктитором, мастером и

29 Василий Великий. Беседа на день святых четыредесяти мучеников и О Святом Духе, 18, 27. Беседы. М.: Изд-во Московского подворья Свято-Троицкой Сергиевой Лавры, 2001. (http://www.pagez.ru/lsn/0290.php). 


\section{Философия и культура 11(83) • 2014}

коллективным зрителем - христианской общиной. Роль соборного сознания в каноническом искусстве чрезвычайно высока. Оно на интуитивном уровне формирует художественное ожидание того, что должен представлять собой тот или иной образ. В постиконоборческую эпоху именно эта соборная интуиция определила тот облик канонической иконы, который мы сегодня видим в памятниках средневе- ковой изобразительности. В то время, как многие святые отцы хотели видеть в изображениях святых нарратив, книгу для неграмотных, дидактические сцены, смысл которых был в сопереживании верующих мученикам и святым, именно соборное сознание, стремившееся быть сопричастным горнему, хотело видеть в образах средоточия мистической силы, и окна в иную, высшую реальность.

\section{Список литературы:}

1. Аверинцев С.С. Поэтика ранневизантийской литературы. Золото в системе символов ранневизантийской культуры. СПб: Азбука-классика, 2004.

2. Аверинцев С.С. Символ // Аверинцев С.С. София-Логос: Словарь. 2-е изд. испр. Киев: Дух і Літера, 2001. С. $155-161$.

3. Аверинцев С.С. Христианский аристотелизм как внутренняя форма западной традиции и проблемы современной России // Риторика и истоки европейской культурной традиции. М., 1996.

4. Алпатов М.В. Искусство Феофана Грека и учение исихастов // Византийский временник. 1972. Т. 33. С. $190-202$.

5. Альберти Л.Б. Три книги о живописи // Альберти Л-Б. Десять книг о зодчестве. В 2-х тт. Т. 2. М., 1937.

6. Бельтинг Х. Образ и культ. История образа до эпохи искусства / Пер. с нем. К.А. Пиганович. М.: Прогресс-Традиция, 2002. $752 \mathrm{c}$.

7. Буркхардт Т. Сакральное искусство Востока и Запада. Принципы и методы. СПб.: Алетейя, 1999. 216 с.

8. Бычков В.В. Малая история византийской эстетики. Киев: Путь к Истине, 1991. 407 с.

9. Василий Великий. Беседа на день святых четыредесяти мучеников и О Святом Духе, 18, 27. Беседы. М.: Изд-во Московского подворья Свято-Троицкой Сергиевой Лавры, 2001. (http://www.pagez.ru/lsn/0290.php).

10. Вельфлин Г. Основные понятия истории искусств. М.: В. Шевчук, 2009. 344 с.

11. Витрувий Марк Поллион. Десять книг об архитектуре / Пер. Ф.А. Петровского. Т. 1. М.: Изд-во Всес. Академии архитектуры, 1936. 331 с.

12. Выготский Л.С. Психология искусства. М.: Искусство, 1986. 341 с.

13. Дворжак М. История искусства как история духа. СПб.: Академический проект, 2001. 336 с.

14. Демус О. Мозаики византийских храмов. М.: Индрик, 2001.160 с.

15. Дионисий Ареопагит. Корпус Ареопагитикум. О церковной иерархии. цит. по Восточные отцы и учители Церкви V века. Антология. М.: Изд-во МФТИ, 2000. (http://krotov.info/acts/05/antolog/page26.htm).

16. Дюрер А. Трактаты. Т. 2. Л.-М.: Искусство, 1957. 254 с.

17. Живов В.М. «Мистагогия» Максима Исповедника и развитие византийской теории образа // Художественный язык средневековья. М.: Наука, 1982. С. 108-127.

18. Иоанн Дамаскин. Три защитительных слова против порицающих святые иконы или изображения. Сергиев Посад: ТСЛ, 1993. $168 \mathrm{c.}$

19. Исаак Сирин. О божественных тайнах и о духовной жизни: Новооткрытые тексты. СПб.: Алетейя, 2003. 256 с.

20. Кассирер Э. Философия символических форм. Т. 1-3. М.: Академический проект, 2011.

21. Климент Александрийский. Увещевание к язычникам / Пер. А.Ю. Братухина. СПб.: Изд-во РХГИ, 1998.208 с.

22. Лидов А.М. Иеротопия. Пространственные иконы и образы-парадигмы в византийской культуре. М.: Феория, 2009. 352 с.

23. Лосев А.Ф. Проблема символа и реалистическое искусство. 2-е изд., испр. М.: Искусство, 1995.320 с.

24. Лосев А.Ф. Художественные каноны как проблема стиля // Вопр. эстетики. 1964. № 6. С. 351-399.

25. Лотман Ю.М. Каноническое искусство как информационный парадокс // Проблема канона в древнем и средневековом искусстве. М., 1973. С. 16-22.

26. Максим Исповедник. Избранные творения / Пер. и коммент. А.И. Сидорова. М.: Паломникъ, 2004. 494 с.

27. Многоценная жемчужина. Литературное творчество сирийцев, коптов и ромеев в 1 тыс. н.э. / Пер. С.С. Аверинцева. М.: Ладомир, 1994.

28. Немезий Эмесский, епископ. О природе человека / Пер. Ф.С. Владимирского. М., 1998.

29. Ориген. О началах. СПб.: Амфора, 2000. 382 с.

30. Отцы и учители церкви III века: Антология в 2-х тт. / Сост. Илларион (Алфеев). М.: Либрис, 1996.464 с.

31. Панофский Э. Перспектива как «символическая форма». СПб.: Азбука-классика, 2004. 336 с.

32. Плотин. Эннеады. T. V. СПб.: Изд. Олега Абышко, 2005.

33. Раушенбах Б.В. Геометрия картины и зрительное восприятие. СПб.: Азбука-классика, 2001. 320 с.

34. Раушенбах Б.В. Пространственные построения в древнерусской живописи. М . : Наука, 1975. 185 с.

35. Ротенберг Е.И. От канона к стилю // Вопросы искусствознания. 1994. № 2-3. С. 175-187.

36. Стоглав / Изд. Д.Е. Кожанчикова. СПб., 1863.

37. Тертуллиан. Апология. М.: АСТ. 2004. (http://www.biblestudy.ru/lib/patrologia/27383-apologiya-tertullian).

38. Успенский Б.А. «Правое» и «левое» в иконописном изображении // Сборник статей по вторичным моделирующим системам. Тарту, 1973. С. 137-145. 
39. Флавий Филострат. Жизнь Аполлония Тианского. М.: Наука, 1985. (http://krotov.info/acts/03/1/filostrat_00.htm).

40. Dvořák M. Kunstgeschichte als Geistesgeschichte («Katakombenmalereien. Die Anfänge der christlichen Kunst»). München 1924. S. 3-40.

41. Grabar A. Plotin et les origines de l'esthétique médiévale // Cahiers archéologiques. Fin de l'antiquité et Moyen Age. 1945. Vol. 1. P. 15-34.

42. Mango C. The art of the Byzantine Empire 312-1453. New Jersey, 1972.

43. Schweizer B. Mimesis und Phantasia // Philologus. 1934. Bd. 39. S. 286-300.

\section{References (transliteration):}

1. Averintsev S.S. Poetika rannevizantiiskoi literatury. Zoloto v sisteme simvolov rannevizantiiskoi kul'tury. SPb: Azbukaklassika, 2004.

2. Averintsev S.S. Simvol // Averintsev S.S. Sofiya-Logos: Slovar'. 2-e izd. ispr. Kiev: Dukh i Litera, 2001. S. $155-161$.

3. Averintsev S.S. Khristianskii aristotelizm kak vnutrennyaya forma zapadnoi traditsii i problemy sovremennoi Rossii // Ritorika i istoki evropeiskoi kul'turnoi traditsii. M., 1996.

4. Alpatov M.V. Iskusstvo Feofana Greka i uchenie isikhastov // Vizantiiskii vremennik. 1972. T. 33. S. $190-202$.

5. $\quad$ Al'berti L.B. Tri knigi o zhivopisi // Al'berti L-B. Desyat' knig o zodchestve. V 2-kh tt. T. 2. M., 1937.

6. Bel'ting X. Obraz i kul't. Istoriya obraza do epokhi iskusstva / Per. s nem. K.A. Piganovich. M.: Progress-Traditsiya, 2002.752 s.

7. Burkkhardt T. Sakral'noe iskusstvo Vostoka i Zapada. Printsipy i metody. SPb.: Aleteiya, 1999. $216 \mathrm{s.}$

8. Bychkov V.V. Malaya istoriya vizantiiskoi estetiki. Kiev: Put' k Istine, 1991. 407 c.

9. Vasilii Velikii. Beseda na den' svyatykh chetyredesyati muchenikov i O Svyatom Dukhe, 18, 27. Besedy. M.: Izd-vo Moskovskogo podvor'ya Svyato-Troitskoi Sergievoi Lavry, 2001. (http://www.pagez.ru/lsn/0290.php).

10. Vel'flin G. Osnovnye ponyatiya istorii iskusstv. M.: V. Shevchuk, 2009. 344 s.

11. Vitruvii Mark Pollion. Desyat' knig ob arkhitekture / Per. FA. Petrovskogo. T. 1. M.: Izd-vo Vses. Akademii arkhitektury, 1936.331 s.

12. Vygotskii L.S. Psikhologiya iskusstva. M.: Iskusstvo, 1986. $341 \mathrm{s.}$

13. Dvorzhak M. Istoriya iskusstva kak istoriya dukha. SPb.: Akademicheskii proekt, 2001. $336 \mathrm{~s}$.

14. Demus 0. Mozaiki vizantiiskikh khramov. M.: Indrik, 2001.160 s.

15. Dionisii Areopagit. Korpus Areopagitikum. 0 tserkovnoi ierarkhii. tsit. po Vostochnye ottsy i uchiteli Tserkvi V veka. Antologiya. M.: Izd-vo MFTI, 2000. (http://krotov.info/acts/05/antolog/page26.htm).

16. Dyurer A. Traktaty. T. 2. L.-M.: Iskusstvo, 1957. $254 \mathrm{s.}$

17. Zhivov V.M. «Mistagogiya» Maksima Ispovednika i razvitie vizantiiskoi teorii obraza // Khudozhestvennyi yazyk srednevekov'ya. M.: Nauka, 1982. S. 108-127.

18. Ioann Damaskin. Tri zashchititel'nykh slova protiv poritsayushchikh svyatye ikony ili izobrazheniya. Sergiev Posad: TSL, 1993. $168 \mathrm{~s}$.

19. Isaak Sirin. O bozhestvennykh tainakh i o dukhovnoi zhizni: Novootkrytye teksty. SPb.: Aleteiya, 2003. $256 \mathrm{~s}$.

20. Kassirer E. Filosofiya simvolicheskikh form. T. 1-3. M.: Akademicheskii proekt, 2011.

21. Kliment Aleksandriiskii. Uveshchevanie k yazychnikam / Per. A.Yu. Bratukhina. SPb.: Izd-vo RKhGI, 1998.208 s.

22. Lidov A.M. Ierotopiya. Prostranstvennye ikony i obrazy-paradigmy v vizantiiskoi kul'ture. M.: Feoriya, 2009.352 s.

23. Losev A.F. Problema simvola i realisticheskoe iskusstvo. 2-e izd., ispr. M.: Iskusstvo, 1995. 320 s.

24. Losev A.F. Khudozhestvennye kanony kak problema stilya // Vopr. Estetiki. 1964. № 6. S. 351-399.

25. Lotman Yu.M. Kanonicheskoe iskusstvo kak informatsionnyi paradoks // Problema kanona v drevnem i srednevekovom iskusstve. M., 1973. S. 16-22.

26. Maksim Ispovednik. Izbrannye tvoreniya / Per. i kommentarii A.I. Sidorova. M.: Palomnik, 2004. 494 s.

27. Mnogotsennaya zhemchuzhina. Literaturnoe tvorchestvo siriitsev, koptov i romeev v 1 tys. n.e. / Per. S.S. Averintseva. M.: Ladomir, 1994.

28. Nemezii Emesskii, episkop. O prirode cheloveka / Per. F.S. Vladimirskogo. M., 1998.

29. Origen. 0 nachalakh. SPb.: Amfora, 2000.382 s.

30. Ottsy i uchiteli tserkvi III veka: Antologiya v dvukh tomakh / Sost. Illarion (Alfeev). M.: Libris, 1996. 464 s.

31. Panofskii E. Perspektiva kak «simvolicheskaya forma». SPb,: Azbuka-klassika, 2004. 336 s.

32. Plotin. Enneady. T. V. SPb.: Izd. Olega Abyshko, 2005.

33. Raushenbakh B.V. Geometriya kartiny i zritel'noe vospriyatie. SPb.: Azbuka-klassika, 2001. $320 \mathrm{~s}$.

34. Raushenbakh B.V. Prostranstvennye postroeniya v drevnerusskoi zhivopisi. M.: Nauka, 1975. $185 \mathrm{~s}$.

35. Rotenberg E.I. Ot kanona k stilyu // Voprosy iskusstvoznaniya 1994. № 2-3. S. 175-187.

36. Stoglav / Izd. D.E. Kozhanchikova. SPb., 1863.

37. Tertullian. Apologiya. M.: AST. 2004. (http://www.biblestudy.ru/lib/patrologia/27383-apologiya-tertullian).

38. Uspenskii B.A. «Pravoe» i «levoe» v ikonopisnom izobrazhenii // Sbornik statei po vtorichnym modeliruyushchim sistemam. Tartu, 1973. S. 137-145.

39. Flavii Filostrat. Zhizn' Apolloniya Tianskogo. M.: Nauka, 1985. (http://krotov.info/acts/03/1/filostrat_00.htm).

40. Dvořák M. Kunstgeschichte als Geistesgeschichte («Katakombenmalereien. Die Anfänge der christlichen Kunst»). München 1924. S. 3-40.

41. Grabar A. Plotin et les origines de l'esthétique médiévale // Cahiers archéologiques. Fin de l'antiquité et Moyen Age. 1945. Vol. 1. P. 15-34.

42. Mango C. The art of the Byzantine Empire 312-1453. New Jersey, 1972.

43. Schweizer B. Mimesis und Phantasia // Philologus. 1934. Bd. 39. S. 286-300. 